\title{
METHODS OF IMPROVING VEGETARIAN FOOD BASED ON REPLACING ANIMAL PRODUCTS BY CHIA SEEDS
}

\author{
I. Ditrykh, L. Bui, A. Hanzha \\ National University of Food Technologies
}

\begin{tabular}{|c|c|}
\hline & \\
\hline $\begin{array}{l}\text { Vegetarian food } \\
\text { Protein } \\
\omega-3 \text { fatty acids } \\
\text { Vitamins } \\
\text { Functional ingredients } \\
\text { Chia seeds }\end{array}$ & $\begin{array}{l}\text { The article is devoted to the substantiation of the results of } \\
\text { studies on the usefulness of the vegetarian diet, and outlines } \\
\text { its main types. Relying on the position of Ukrainian doctors } \\
\text { and the work of foreign scientists, the main advantages and } \\
\text { disadvantages of vegetarianism are presented. The use of }\end{array}$ \\
\hline $\begin{array}{l}\text { Article history: } \\
\text { Received 15.05.2017 } \\
\text { Received in revised form } \\
05.06 .2017 \\
\text { Accepted } 21.06 .2017 \\
\end{array}$ & $\begin{array}{l}\text { vegetarians is proposed in order to pro } \\
\text { necessary nutrients. We characterized } \\
\text { sition of chia seeds and their interch } \\
\text { food, which should be used in the der }\end{array}$ \\
\hline $\begin{array}{l}\text { Corresponding author: } \\
\text { I. Ditrykh } \\
\text { E-mail: } \\
\text { irindtr@gmail.com }\end{array}$ & $\begin{array}{l}\text { protein and } \omega-3 \text { unsaturated fatty acids, is proposed. For this } \\
\text { dish the technology maps are developed and its chemical } \\
\text { composition is presented, confirming the feasibility of using } \\
\text { chia seeds as a functional ingredient. }\end{array}$ \\
\hline
\end{tabular}

DOI: $10.24263 / 2225-2924-2017-23-4-27$

\section{СПОСОБИ УДОСКОНАЛЕННЯ ХАРЧУВАННЯ ВЕГЕТАРІАНЦІВ НА ОСНОВІ ЗАМІНИ ПРОДУКТІВ ТВАРИННОГО ПОХОДХЕННЯ НАСІННЯМ ЧІА}

\author{
І.В. Дітріх, Л.М. Буй, А.А. Ганжа \\ Національний університет харчових технологій
}

Статтю присвячено обтрунтуванню результатів досліджень щодо корисності вегетаріанського способу харчування, окреслено основні його види. Спираючись на позииії українських лікарів і праці зарубіжних учених, представлено головні переваги та недоліки вегетаріанства. Запропоновано використання альтернативної сировини - насіння чіа - у раціоні вегетаріаниів з метою забезпечення організму необхідними нутрієнтами. Охарактеризовано хімічний склад насіння чіа та його взаємозамінності з основними продуктами харчування, які доцільно використовувати при розробках вегетаріанського меню різних видів. Запропоновано страву функиіонального призначення "Салат з грейпфрутом, ламінарією та насінням чіа», збагачену білком $і$ $\omega-3$ ненасиченими жирними кислотами, на яку розроблено технологічні карту та схему приготування та наведено хімічний склад, що підтверджує доцільність використання насіння чіа як функиіонального інгредієнта. 
Ключові слова: вегетаріанське харчування, білок, $\omega$-3 ненасичені жирні кислоти, вітаміни, функціональний інгредієнт, насіння чіа.

Постановка проблеми. Останніми роками підвищився інтерес населення до різних видів нетрадиційного харчування. Під нетрадиційними розуміють такі види харчування, які відрізняються від прийнятих науково-обгрунтованих принципів і способів харчування. У західних країнах все більш популярним стає вегетаріанський спосіб харчування.

Вегетаріанець - споживач, який не їсть м'ясо або рибу, а іноді й інші продукти тваринного походження, виходячи з моральних, релігійних причин або особливостей здоров'я [1]. Розрізняють декілька видів вегетаріанства:

- лакто-вегетаріанство - допускається вживання молочних продуктів;

- ово-вегетаріанство - допускається вживання яєць;

- лакто-ово-вегетаріанство - допускається вживання яєць і молочних продуктів;

- веганство (суворе вегетаріанство) - забороняються вживання всіх продуктів тваринного походження (у тому числі сичужного ферменту, желатину, меду тощо) [2].

Останнім часом дедалі більшої популярності набуває органічна продукція без додавання гормонів, антибіотиків, стимуляторів росту тощо. Заклади ресторанного господарства намагаються вводити такі продукти до раціону харчування, оскільки при їх споживанні організм отримує різні необхідні йому вітаміни, мінерали, а також зміцнюється імунітет [3].

Мета статті полягає у дослідженні та обгрунтуванні доцільності використання альтернативної сировини - насіння чіа - у раціоні вегетаріанців $\mathrm{i}$ розробка рецептури страви «Салат з грейпфрутом, ламінарією та насінням чіа» на основі принципів нутріціології та харчової комбінаторики.

Матеріали і методи. Основу дослідження склали діалектичний метод наукового пізнання, методи теоретичного узагальнення, наукової індукції та дедукції, синтезу, абстракції, методи системного, структурного, компаративного, математичного аналізу, графічний метод, праці вітчизняних і зарубіжних вчених, присвячених проблемам вегетаріанського способу харчування.

Результати і обговорення. Існують різні думки щодо корисності вегетаріанської дієти. Згідно з офіційною відповіддю МОЗ України від 03.06.2014 № 05.01-20/17/694/3ПI-14/15332 на запит споживачів від 29 травня 2014 року, наукові дослідження стосовно впливу вегетаріанського способу харчування на здоров'я людини не проводились, проте цей спосіб відповідає принципам доказової медицини [4]. Вегетаріанська дієта може бути використана дорослими чоловіками та жінками. Водночас такий спосіб харчування є небажаним і може бути небезпечним для здоров'я дітей та підлітків, вагітних і жінокгодувальниць, осіб похилого віку, а також при низці хронічних захворювань внутрішніх органів. Перед прийняттям рішення щодо переходу на виключно вегетаріанське харчування доцільно отримати консультацію лікаря стосовно можливих ризиків для здоров'я і необхідних заходів щодо їх запобігання[5].

$\mathrm{y}$ результаті дослідження даного питання провідними спеціалістами Інституту педіатрії, акушерства і гінекології Національної академії медичних 
наук України було сформульовано позицію лікарів щодо вегетаріанства: «перевагою вегетаріанських дієт є високий вміст вуглеводів, харчової клітковини, омега-6 жирних кислот, вітаміну Е, фолієвої кислоти, вітаміну $\mathrm{C}$, каротиноїдів та магнію. Поряд з цим вегетаріанські дієти характеризуються низьким вмістом білків, насичених жирів, довголанцюгових $\omega-3$ жирних кислот, вітаміну B12, ретинолу, вітаміну D, кальцію, цинку та (іноді) заліза» [4]. За дослідженнями британських вчених П. Апплебі, Т. Кея, М. Бурра, Дж. Манна, вегетаріанці мають нижчу смертність серед населення в цілому [6].

Таким чином, вегетаріанська дієта має свої переваги та недоліки. Для збалансованого харчування страви, що входять до раціону вегетаріанців, необхідно збагачувати дефіцитними поживними речовинами, які містяться у продуктах харчування. Таким альтернативним функціональним інгредієнтом страв може бути насіння чіа, у якому міститься значна кількість білків та $\omega-3$ жирних кислот.

Чіа біла, або Шавлія іспанська (лат. Salvia hispanica) — рослина родини Ясноткові, роду Шавлія. У кулінарії також використовується близькоспоріднений вид Salvia columbariae [7]. Батьківщиною рослини $є$ Центральна і Південна Мексика, а також Гватемала. На сьогоднішній день чіа культивується у багатьох країнах Південної Америки та в Австралії.

У табл. 1 наведено дані, що стосуються вмісту поживних харчових речовин у насінні чіа.

Таблиця 1. Вміст поживних харчових речовин у насінні чіа [8]

\begin{tabular}{|c|c|}
\hline Харчові речовини & Вміст у 100 г \\
\hline Білок, г & $20-22$ \\
\hline Жири, г & $30-35$ \\
\hline Вуглеводи, г & $25-41$ \\
\hline Харчові волокна, г & $18-30$ \\
\hline Зола, г & $4-6$ \\
\hline Насичені жирні кислоти, г & 3,3 \\
\hline Ненасичені жирні кислоти, г & 27 \\
\hline У тому числі $\omega-3$, г & 21 \\
\hline \multicolumn{2}{|l|}{ Мінеральні речовини, мг: } \\
\hline Кальцій & 536 \\
\hline Магній & 350,3 \\
\hline Натрій & 12,2 \\
\hline Калій & 564 \\
\hline Фосфор & 751 \\
\hline Залізо & 6,3 \\
\hline Цинк & 4,4 \\
\hline Мідь & 1400 \\
\hline \multicolumn{2}{|l|}{ Вітаміни, мг } \\
\hline Вітамін $\mathrm{B}_{1}$ & 0,45 \\
\hline Вітамін $\mathrm{B}_{2}$ & 0,04 \\
\hline Вітамін $\mathrm{B}_{6}$ & 0,1 \\
\hline Вітамін $\mathrm{B}_{9}$, мкг & 110 \\
\hline Вітамін C & 5,4 \\
\hline Вітамін Е & 1,16 \\
\hline Вітамін РP & 6,13 \\
\hline Енергетична цінність, кДж & 1964 \\
\hline
\end{tabular}


Дані, наведені в табл.1, слід враховувати при розробці вегетаріанського меню різних видів, адже насіння чіа є джерелом значної кількості білків, мінеральних речовин, вітамінів, а також омега-3 ненасичених жирних кислот і за своїм хімічним складом може замінювати продукти тваринного походження. У табл. 2 наведено порівняльний аналіз хімічного складу чіа і продуктів харчування тваринного походження.

Таблиця 2. Порівняльна характеристика хімічного складу насіння чіа і продуктів харчування тваринного походження [8; 9]

\begin{tabular}{|c|c|c|c|c|c|c|}
\hline \multirow[b]{2}{*}{ Харчові речовини } & \multirow{2}{*}{$\begin{array}{c}\text { Норми } \\
\text { вживання, г }\end{array}$} & \multicolumn{5}{|c|}{ Вміст речовин в 100 г } \\
\hline & & Насіння чіа & $\begin{array}{c}\text { Риба } \\
\text { (лосось) }\end{array}$ & $\begin{array}{c}\text { М'ясо } \\
\text { (свинина) }\end{array}$ & Молоко & Яйця \\
\hline Білок, г & $80-100$ & 22 & 20 & 19,4 & 2,9 & 12,7 \\
\hline Жири, г & $80-100$ & $30-35$ & 8,1 & 7,1 & 2,5 & 11,5 \\
\hline Вуглеводи, г & 450 & $25-41$ & - & - & 4,8 & 0,7 \\
\hline Харчові волокна, г & $25-30$ & $18-30$ & - & - & - & - \\
\hline $\begin{array}{c}\text { Ненасичені жирні } \\
\text { кислоти, Г } \\
\end{array}$ & $2-6$ & 27 & 1,5 & 1,5 & 1,7 & 1,26 \\
\hline $\begin{array}{c}\text { У тому числі } \\
\omega-3, \text { г } \\
\end{array}$ & $2-6$ & 21 & 4,4 & 1,2 & 0,7 & 1,1 \\
\hline \multicolumn{7}{|c|}{ Мінеральні речовини, мг: } \\
\hline Кальцій & $800-1200$ & 536 & 15 & 8 & 120 & 55 \\
\hline Магній & $350-500$ & 350,3 & 25 & 26 & 14 & 12 \\
\hline Натрій & 1000 & 12,2 & 45 & 41 & 50 & 134 \\
\hline Калій & $1100-2000$ & 564 & 420 & 345 & 146 & 140 \\
\hline Фосфор & 500 & 751 & 210 & 220 & 90 & 192 \\
\hline Залізо & $10-20$ & 6,3 & 0,8 & 1,6 & 0,1 & 2,5 \\
\hline Цинк & $15-20$ & 4,4 & 0,64 & 2,07 & 0,4 & 1,11 \\
\hline Мідь, мкг & 1400 & 1400 & 250 & 96 & 12 & 83 \\
\hline \multicolumn{7}{|c|}{ Вітаміни, мг } \\
\hline Вітамін $\mathrm{B}_{1}$ & $1,6-2,5$ & 0,45 & 0,23 & 1,45 & 0,04 & 0,07 \\
\hline Вітамін $\mathrm{B}_{2}$ & $1,3-2,4$ & 0,04 & 0,25 & 0,16 & 0,15 & 0,44 \\
\hline 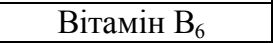 & $1,7-2,2$ & 0,1 & 0,8 & 0,5 & 0,05 & 0,14 \\
\hline Вітамін $\mathrm{B}_{9}$, мкг & 200 & 110 & 25 & 6,1 & 5 & 7 \\
\hline Вітамін C & $70-100$ & 5,4 & 1 & - & 1,3 & - \\
\hline Вітамін Е & $8-10$ & 1,16 & 1,8 & 0,5 & - & 0,6 \\
\hline Вітамін РP & 100 & 6,13 & 9,4 & 2,63 & 0,8 & 3,6 \\
\hline $\begin{array}{c}\text { Енергетична } \\
\text { цінність, ккал }\end{array}$ & & 472 & 153 & 142 & 54 & 157 \\
\hline
\end{tabular}

Аналіз даних, наведених у табл. 2, свідчить про те, що насіння чіа містить вдвічі більше білка, ніж у яйцях і в 7 разів більше, ніж у молоці. Жирів у чіа в 3 рази більше, ніж в яйцях, в 4 рази більше, ніж в рибі, в 5 разів більше, ніж у м'ясі і в 15 разів більше, ніж у молоці. Вміст $\omega-3$ ненасичених жирних кислот у насінні чіа в 4 рази більший, ніж у вищенаведених продуктах (див. рис. 1). Вміст мінеральних речовин і вітамінів у насінні чіа вищий порівняно із продуктами тваринного походження за такими елементами: кальцієм магнієм, фосфором, залізом, міддю та вітамінами $\mathrm{B}_{9}$ та $\mathrm{C}$. 


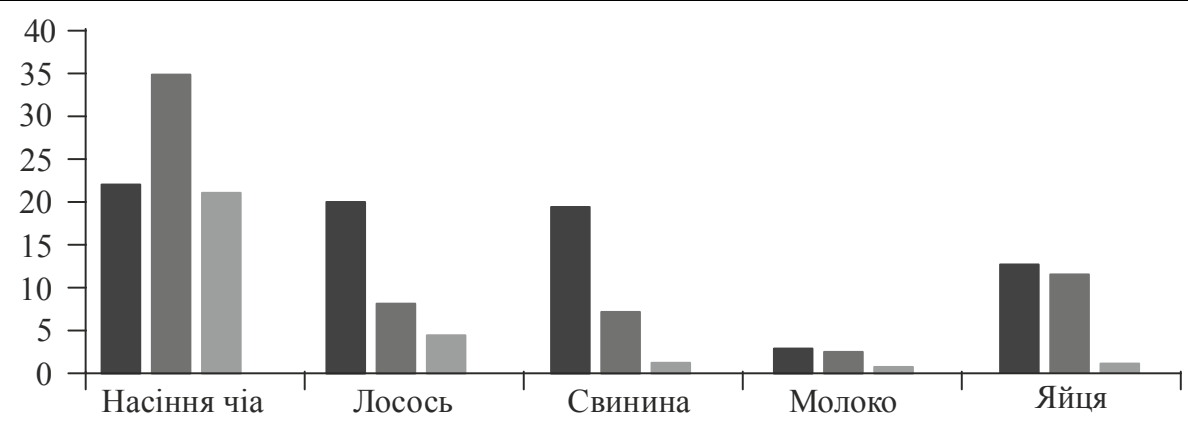

Білки Ш Жири помега-3 НЖК

Рис. 1. Вміст поживних речовин у насінні чіа та продуктах харчування тваринного походження

Посилаючись на середні показники добових потреб організму людини у поживних речовинах та мінеральних елементах визначено, що 25 г насіння чіа є оптимальною кількістю для щоденного споживання [9].

На основі вищенаведених даних доцільно визначити ступінь взаємозамінності досліджуваних продуктів за нутрієнтним складом (табл. 3).

Таблиия 3. Взаємозамінність насіння чіа з продуктами тваринного походження

\begin{tabular}{|c|c|c|c|c|c|}
\hline \multirow{2}{*}{$\begin{array}{c}\text { Харчові } \\
\text { речовини }\end{array}$} & \multirow{2}{*}{$\begin{array}{c}\text { Вміст речовин } \\
\text { в } 25 \text { г Чіа }\end{array}$} & \multicolumn{4}{|c|}{$\begin{array}{l}\text { Кількість продукту, } \\
\text { що замінює } 25 \text { г Чіа, г }\end{array}$} \\
\hline & & Риба (лосось) & $\begin{array}{c}\text { М'ясо } \\
\text { (свинина) }\end{array}$ & Молоко & Яйця \\
\hline 1 & 2 & 3 & 4 & 5 & 6 \\
\hline Білки & 5,5 & 27,5 & 28,4 & 189,7 & 43,3 \\
\hline Жири & 8,75 & 108 & 123,2 & 350 & 76,1 \\
\hline Вуглеводи & 8,25 & - & - & 171,9 & 777,5 \\
\hline$\omega-3$ НЖК & 5,25 & 119,3 & 437,5 & 750 & 477,3 \\
\hline Кальцій & 134 & 893,3 & 1675 & 111,6 & 243,6 \\
\hline Магній & 87,6 & 350,4 & 336,9 & 625,7 & 730 \\
\hline Фосфор & 187,75 & 89,4 & 85,3 & 208,6 & 97,8 \\
\hline Залізо & 1,575 & 196,9 & 98,4 & 1575 & 63 \\
\hline Мідь, мкг & 350 & 140 & 364,6 & 2916,7 & 421,7 \\
\hline Вітамін В9 & 27,5 & 110 & 450,8 & 750 & 392,9 \\
\hline Вітамін C & 1,35 & 135 & - & 103,8 & - \\
\hline
\end{tabular}

Дані, наведені в табл. 3, доводять, що насіння чіа є інгредієнтом, який в певній мірі може бути замінником продуктів тваринного походження в раціоні вегетаріанців.

Насіння чіа за кольором буває двох видів: біле і чорне. Воно має нейтральний смак та аромат, тому може бути інгредієнтом багатьох страв. У зв'язку з цим для дослідження було запропоновано страву «Салат з грейпфрутом та ламінарією», збагачену насінням чіа, технологічна карта якої наведена у таблиці 4. 
Таблиия 4. Технологічна карта на функціональну страву «Салат з грейпфрутом, ламінарією і насінням чіа»

\begin{tabular}{|c|c|c|c|c|}
\hline \multirow{2}{*}{ № } & Найменування & \multicolumn{2}{|c|}{ Маса сировини, г } & Нормативна документація \\
\cline { 3 - 5 } п.п & сировини & 1 Б & $1 \mathrm{H}$ & \\
\hline 1. & Рукола & 33 & 30 & ДСТУ318-91 \\
\hline 2. & Салатний лист & 33 & 30 & ДСТУ2660-94 \\
\hline 3. & Лимонний сік & 5 & 5 & ДСТУ3234-95 \\
\hline 4. & Грейпфрут & 70 & 60 & ДСТУ7035-09 \\
\hline 5. & Ламінарія & 60 & 60 & ДСТУ3246-95 \\
\hline 6. & Оливкова олія & 5 & 5 & ДСТУ3233-95 \\
\hline 7. & Насіння чіа & 10 & 10 & ДСТУ4637-06 \\
\hline & Вихід: & & 200 & \\
\hline
\end{tabular}

Загальна технологічна схема приготування салату з грейпфрутом і ламінарією $з$ додаванням насіння чіа представлена на рис. 2.

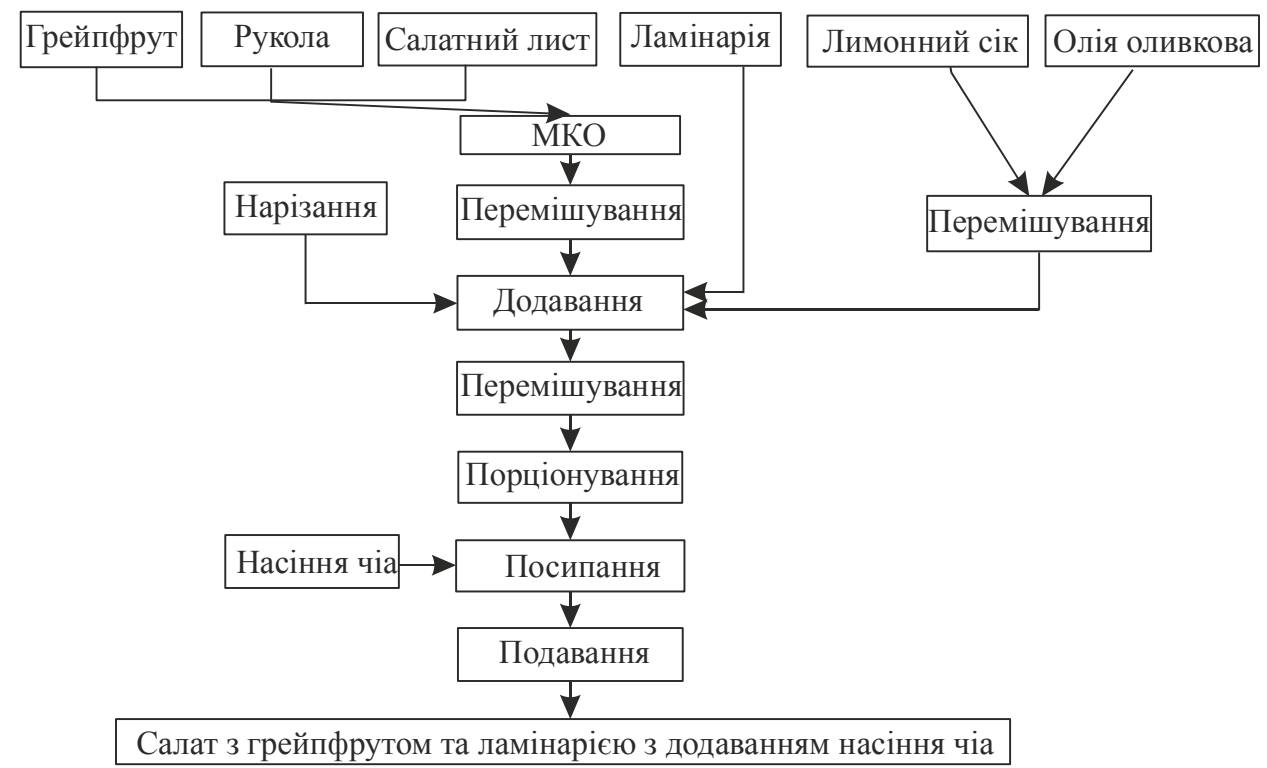

Рис. 2. Загальна технологічна схема приготування салату з грейпфрутом i ламінарією $з$ додаванням насіння чіа

Грунтуючись на потребі вегетаріанців у білках і $\omega-3$ ненасичених жирних кислотах в страву як функціональний інгрідієнт було додано насіння чіа. Вміст хімічних речовин у страві наведено в табл. 5.

Табличя 5. Вміст хімічних речовин у страві «Салат 3 грейпфрутом, ламінарією та насінням чіа»

\begin{tabular}{|c|c|c|c|c|c|c|c|c|c|}
\hline $\begin{array}{c}\text { Харчові } \\
\text { речовини }\end{array}$ & Рукола & $\begin{array}{c}\text { Листя } \\
\text { салату }\end{array}$ & $\begin{array}{c}\text { Грейп- } \\
\text { фрут }\end{array}$ & $\begin{array}{c}\text { Ламі- } \\
\text { нарія }\end{array}$ & $\begin{array}{c}\text { Лимо- } \\
\text { нний } \\
\text { сік }\end{array}$ & $\begin{array}{c}\text { Олія } \\
\text { олив- } \\
\text { кова }\end{array}$ & $\begin{array}{c}\text { Насі- } \\
\text { ння } \\
\text { чіа }\end{array}$ & Всього & $\begin{array}{c}\text { Забезпе- } \\
\text { чення до- } \\
\text { бової по- } \\
\text { треби, \% }\end{array}$ \\
\hline 1 & 2 & 3 & 4 & 5 & 6 & 7 & 8 & 9 & 10 \\
\hline Білок, г & 0,77 & 0,45 & 0,42 & 0,59 & 0,04 & - & 2,1 & 4,37 & 5,5 \\
\hline Жири, г & 0,2 & 0,06 & 0,12 & 0,13 & 0,01 & 4,99 & 3,3 & 8,81 & 11,0 \\
\hline
\end{tabular}


Продовження табл. 5

\begin{tabular}{|c|c|c|c|c|c|c|c|c|c|}
\hline 1 & 2 & 3 & 4 & 5 & 6 & 7 & 8 & 9 & 10 \\
\hline Вуглеводи, г & 1,09 & 0,6 & 3,9 & 1,95 & 0,15 & - & 3,3 & 10,99 & 2,4 \\
\hline $\begin{array}{c}\text { Харчові } \\
\text { волокна, г }\end{array}$ & 0,48 & 0,36 & 1,08 & 0,39 & 0,1 & 一 & 2,5 & 4,91 & 19,64 \\
\hline$\omega-3$ НЖК , г & 0,05 & - & - & - & - & 0,55 & 2,1 & 2,7 & 54,0 \\
\hline \multicolumn{10}{|l|}{$\begin{array}{c}\text { Мінеральні } \\
\text { речовини, мг: }\end{array}$} \\
\hline Кальцій & 48 & 23,1 & 13,8 & 26 & 2 & - & 53,6 & 166,5 & 16,7 \\
\hline Магній & 14,1 & 12 & 6 & 110,5 & 0,6 & - & 35 & 178,2 & 44,5 \\
\hline Натрій & 8,1 & 2,4 & 7,8 & 338 & 0,55 & - & 1,2 & 358,05 & 35,8 \\
\hline Калій & 110,7 & 66 & 110,4 & 630,5 & 8,15 & - & 56,4 & 982,15 & 64,5 \\
\hline Фосфор & 15,6 & 10,2 & 10,8 & 35,75 & 1,1 & 0,1 & 75,1 & 148,65 & 29,7 \\
\hline Залізо & 0,44 & 0,18 & 0,3 & 10,4 & 0,03 & 0,02 & 0,63 & 12 & 80 \\
\hline Цинк & 0,14 & 0,08 & 0,04 & - & 0,01 & - & 0,4 & 0,67 & 3,9 \\
\hline Мідь, мкг & 22,8 & 36 & 28,2 & - & 12 & - & 140 & 239 & 17,1 \\
\hline \multicolumn{10}{|l|}{ Вітаміни, мг } \\
\hline Вітамін $\mathrm{B}_{1}$ & 0,01 & 0,01 & 0,02 & 0,03 & 0,002 & - & 0,045 & 0,117 & 5,85 \\
\hline Вітамін $\mathrm{B}_{2}$ & 0,02 & 0,02 & 0,01 & 0,04 & 0,001 & - & 0,004 & 0,095 & 4,75 \\
\hline 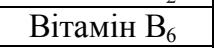 & 0,02 & 0,05 & 0,03 & 0,01 & 0,003 & - & 0,1 & 0,213 & 10,65 \\
\hline Вітамін $\mathrm{B}_{9}$, мкг & 29,1 & 14,4 & 6 & 1,49 & 0,45 & - & 11 & 62,44 & 31,22 \\
\hline Вітамін C & 4,5 & 4,5 & 20,64 & 1,3 & 2 & - & 0,54 & 33,48 & 39,38 \\
\hline Вітамін E & 0,13 & 0,21 & 0,08 & - & 0,01 & 0,61 & 0,11 & 1,15 & 12,77 \\
\hline Вітамін РP & 0,09 & 0,27 & 0,15 & 0,26 & 0,01 & - & 0,61 & 1,39 & 1,39 \\
\hline $\begin{array}{l}\text { Енергетична } \\
\text { цінність, кДж }\end{array}$ & 31,2 & 19,9 & 79,9 & 67,3 & 7,1 & 186,8 & 47,2 & 439,4 & \\
\hline
\end{tabular}

Аналіз даних табл. 5 показав, що насіння чіа забезпечує організм людини певною кількістю поживних речовин.

\section{Висновки}

Представлено переваги та недоліки вегетаріанського способу харчування, визначено дефіцитні нутрієнти у харчуванні веганів. Проведено порівняльний аналіз хімічного складу насіння чіа та харчових продуктів тваринного походження. Доведено, що насіння рослини роду Шавлія (чіа) може бути функціональним інгрідієнтом у стравах харчового раціону вегетаріанців, який сприятиме збалансуванню харчування.

\section{Література}

1. English Oxford Living Dictionaries [Електронний ресурс]. — Режим доступу : https://en.oxforddictionaries.com/.

2. The American Journal of Clinical Nytrition [Електронний ресурс]. — Режим доступу : http://ajcn.nutrition.org/content/78/1/3.full.

3. Неміріч O.B. Технологічні аспекти виготовлення збивної страви 3 порошком 3 топінамбуру / О.В. Нєміріч, М.А. Возненко, I.I. Бондаренко, Б.О. Яценко // Науковий вісник ЛНУВМБТ імені С.3. Гжицького. — 2016. — Т. 18, № 2(68). — С. 32-36.

4. Вегетаріанське харчування [Електронний ресурс]. - Режим доступу : https://dostup.pravda.com.ua/request/vieghietarianskie_kharchuvannia.

5. Позиція MO3 України щодо вегетаріанства [Електронний ресурс]. — Режим доступу: https: //7promeniv.com.ua/kharchuvannia/vehetarianstvo/1400-pozytsiia-moz-ukrainyshchodo-vehetarianstva.html\#vidp_2. 
6. Paul N Appleby, Timothy J Key, Margaret Thorogood, Michael L Burr, Jim Mann Mortality in British vegetarians [Електронний pecypc]. - Режим доступу : file:///C:/Users/Admin/Desktop/1.pdf.

7. Бернардино де Саагун, Куприенко С.А. Общая история о делах Новой Испании. Книги X-XI: Познания астеков в медицине и ботанике / Ред. и пер. С. А. Куприенко. Київ : Видавець Купрієнко С.А., 2013. - 218 с.

8. Конь И.Я. Отчет по научно-исследовательской работе по теме: «Медико-биологическое обоснование возможности использования муки из семан растенияв чиа в питании детей старше трех лет», выполненной в рамках договора № 74-д от 17 декабря 2012 года / И.Я. Конь, Н.М. Шилина, М.В. Гмошинская, В.В. Бессонов, А.А. Кочеткова, М.А. Гурченкова [Електронний ресурс]. - Режим доступу : http://oreluniver.ru/public/file/archive/1_2017.pdf.

9. Химический состав и энергетическая ценность пищевых продуктов: справочник Мак Канса и Уиддоусона / пер. с англ. под общ. ред. д-ра мед. наук А.К. Батурина. Санкт-Петербург : Профессия, 2006. - 416 с. 